\title{
As Audiências Públicas no STF: a adoção de um modelo cooperativo de controle de constitucionalidade das normas
}

\author{
Public Hearings in the STF: the adoption of a cooperative \\ model of judicial review
}

Jadson Correia de Oliveira

Faculdade Sete de Setembro, Paulo Afonso - BA, Brasil

Ivan Luiz da Silva

Faculdade Sete de Setembro, Paulo Afonso - BA, Brasil

Fernando Sérgio Tenório de Amorim

Faculdade Sete de Setembro, Paulo Afonso - BA, Brasil

Resumo: O presente trabalho pretende analisar a abertura do processo constitucional objetivo por meio da realização de audiências públicas. Faz-se um estudo sobre a atividade jurisdicional e seu exercício, de acordo com a evolução da própria sociedade a respeito dos seus valores, sob pena de se fossilizar o Direito e afastá-lo da sociedade. Assim, utiliza como exemplo da aplicação dos temas abordados a forma como foram organizadas as audiências públicas. A pesquisa conclui que a subjetivização do controle concentrado de constitucionalidade reflete uma expansão da cidadania e da própria democracia, quando cria um espaço deliberativo para viabilizar o acesso social ao processo de construção da decisão judicial.

Palavras-chave: Legitimidade das Decisões Proferidas no Controle Objetivo de Constitucionalidade. Diálogo Social no STF. Audiências Públicas e Amicus Curiae no Controle Concentrado de Constitucionalidade.
Abstract: This paper to examine the thesis about the interpreters of the Constitution, the pluralization of the debate and the constitutional process. The starting point for such a study is due to the recent positions taken by the Supreme Court (STF) based on democratic participation in their decisions. The study presents each of the major themes of the interpreters of the Constitution, in order not to fossilize the law and/or not allowing that it be far away from the whole society. By logical consequence, it is mandatory to near law and society. This happens due to the occurence of such activity at the level of problematic interpretation issue, which permeates the concerning results.

Keywords: Judicial Review Legitimacy. Social Dialogue Into the STF. Public Deliberation and the Amicus Curiae Into the Objective Judicial Review.

Recebido em: 09/12/2017

Revisado em: 16/03/2018

Aprovado em: 28/03/2018 


\section{Introdução}

O presente artigo destina-se a analisar um problema de cunho processual constitucional, qual seja: o de que o amplo rol de direitos e garantias fundamentais previstos na Carta Magna de 1988 não possui um disciplinamento procedimental adequado, em especial, a questão da participação social no processo de construção da decisão jurisdicional, proferida em sede de controle abstrato de constitucionalidade.

Destaque-se que a própria participação procedimental é vista por Canotilho, como um direito fundamental. Para ele, é condição de autodeterminação efetiva que o cidadão disponha de instrumentos jurídico-processuais que viabilizem a capacidade de influenciar as decisões proferidas pelos poderes públicos (CANOTILHO, 2008).

As audiências públicas possuem previsão, em sede de STF, no Regimento Interno do Supremo alterado pela emenda regimental número 29, de 18 de fevereiro de 2009, cujas principais características são: a) discricionariedade do ministro relator do processo quanto à convocação dos interessados; e b) ainda no campo da discricionariedade há a seleção dos interessados, a ordem dos trabalhos e o tempo que cada um terá para se expor sua opinião acerca da matéria.

Outro aspecto que merece menção é o atinente ao fato da emenda regimental número 29 ter ampliado o campo de incidência das audiências públicas permitindo a sua realização, inclusive, nas ações de controle difuso de constitucionalidade.

\section{Fudamentos Principiológicos das Audiências Públicas}

Ao tratar o tema das audiências públicas e levando-se em consideração que se trata de um instrumento de participação popular no processo de formação de decisões estatais, de logo se destacam, entre os princípios fundamentais de tal instituto o democrático, o da cidadania e o da participação (MOREIRA NETO, 2007). 
Conforme abordado em capítulo específico deste trabalho, o princípio democrático exige a conformação do agir estatal com a vontade popular, ou seja, traz a necessidade da observância da legitimidade, qualificando o estado brasileiro como democrático de Direito (artigo $1^{\circ}$, caput, da Constituição da República/88).

Consequências lógicas do princípio supracitado são os da cidadania, que confere o necessário reconhecimento de que no povo encontra-se o poder para as decisões sobre as coisas públicas e o da participação, interessando para este trabalho o seu viés, não apenas da escolha dos representantes dos poderes Legislativo e Executivo, mas, sim, o da escolha do conteúdo das decisões públicas.

A cidadania traz em seu bojo a necessidade de motivação da atuação estatal, sob pena dessa cidadania ser entendida como arbitrária e impositiva, fatores que afastam, inevitavelmente, a sociedade do Estado. Nesse contexto, o que se busca com a motivação é a identificação das possíveis razões de decidir.

Inafastável a esses princípios encontra-se o da publicidade, no sentido de direito à informação, que se presta para, além de viabilizar a própria participação da sociedade na audiência, a fundamentação da opinião esposada no momento da oitiva popular, uma vez que o expositor deve ter o mais amplo acesso possível a uma gama de informações para que traga a sua da forma mais completa possível.

Em sede complementar, há o princípio da realidade, mais voltado à esfera do direito administrativo, segundo o qual a decisão proferida após o procedimento da audiência pública tem maior eficácia, visto que resulta da aplicação do senso comum.

Por fim, deve-se falar sobre o princípio do devido processo legal, pois, uma vez que se trata de um procedimento o mesmo deve ser seguido a fim de que se garanta o seu sentido formal. Agregue-se ainda aos dizeres o sentido substancial do due processo of law, que traz a necessidade de que se observe os princípios da proporcionalidade e da razoabilidade a fim de que sejam evitados excessos nas regras trazidas ao instituto processual uma vez que deve-se buscar a garantia de um processo como 
procedimento em contraditório em paridade de armas para que se alcance uma decisão substancialmente válida.

\section{A Utilização das Audiências Públicas no Controle de Constitu- cionalidade Realizado no Brasil}

Este ensaio preocupa-se, também, com o estudo da legitimidade da jurisdição constitucional por meio da abertura do processo constitucional objetivo, sem desrespeitar o procedimento ou enfraquecer o próprio modelo de controle concentrado.

Ao mesmo tempo, deve-se aludir ao fenômeno que a opinião pública exerce sobre os magistrados, com destaque para os componentes do $\mathrm{STF}$, até mesmo porque, em regra, suas decisões repercutem sobre toda a sociedade e não apenas entre as partes envolvidas no litígio.

Contudo, conferir legitimação social para uma decisão jurisdicional não se resume apenas em conformar o decisum à opinião da maioria.

O que se pretende demonstrar é a necessidade da criação de uma arena de discussão que não se limite a atender aos clamores sociais, mas sim que viabilize uma discussão pautada por argumentos técnico-científicos.

É importante que se diga, ainda, que a principal e talvez a incontornável crítica que permeia o instituto das audiências públicas está relacionada a saber se os seus realizadores efetivamente levam em consideração as opiniões esposadas.

A verdade é que essa dúvida ainda devem permear durante muito tempo os debates jurídicos sobre o tema. No entanto, Moreira Neto diferencia o debate público, entendido como processo de participação aberto a indivíduos e grupos sociais que visam a contribuir para a melhor decisão, das audiências públicas, que, na visão do autor, possuiriam um maior rigor formal uma vez que possuiria eficácia específica e vinculatória e obrigaria a atuação nos termos do resultado obtido. Por isso que as audiências só poderiam ser realizadas mediante lei instituidora onde haja a definição do seu procedimento e da sua eficácia (MOREIRA NETO, 2007). 
Por enquanto, apesar dessa interessantíssima construção doutrinária, não há lei em sentido estrito que possa prever a realização de audiências públicas no controle concentrado de constitucionalidade realizado pelo STF, sendo a sua previsão apenas regimental, mesmo sabendo que o Supremo, por diversas vezes, ratificou o seu entendimento de que o seu regimento interno possui status de lei.

Dito de outra forma, mostra-se mais conveniente e condizente com o atual estágio em que se encontra a sociedade brasileira e a sua maturidade quanto à vivência constitucional que o Estado, nesse caso representado pelo Judiciário, atue como um verdadeiro parceiro, ao invés de um órgão coercitivo.

Esse modelo que se busca ver empregado é o deliberativo e pauta-se pelo motivo, sobretudo, da democracia brasileira não estar sedimentada numa base deliberativa. Por isso mesmo é que a guarda da Constituição coube ao Judiciário, ao STF, porque lá o debate não se esgota facilmente, pelo contrário, se mantém vivo, e suas decisões são públicas e fundamentadas. O déficit de deliberação da democracia brasileira é aliviado pelo processo judicial, que contribuiu, sobremaneira, para viabilizar o debate a respeito dos direitos individuais e de seus limites (PINTO, 2009).

Em sua pesquisa sobre o tema, Carolina Vestena demonstra uma visão mais cética, acerca do impacto das audiências públicas realizadas pelo STF no processo de construção da decisão. A autora expõe três problemas como sendo os principais entraves para o viés democrático-participativo das audiências públicas: a) o emprego, pelo regimento interno do STF, de expressões que possuem um alto grau de abstração, tais como "pessoas com autoridade e experiência no tema", e que culminam restringindo o acesso de membros da sociedade civil e de movimentos sociais aos debates; b) a inexistência de critérios objetivos quanto à escolha dos participantes, e; c) criação de um cenário de audiência no qual os expositores são dispostos em posições antagônicas, como se adversários fossem, o que diminui o aspecto colaborativo nesses processos (VESTENA, 2010).

No sentido de complementar os dizeres acima, Habermas (1997, p. 99) conceitua sociedade civil ou espaço público ao narrar que: 
O seu núcleo institucional é formado por associações e organizações livres, não estatais e não econômicas, as quais ancoram as estruturas de comunicação da esfera pública nos componentes sociais do mundo da vida. A sociedade civil compõe-se de movimentos, organizações e associações, os quais captam os ecos dos problemas sociais que ressoam nas esferas privadas, condensam-nos e os transmitem, a seguir, para a esfera pública política.

Destaque-se que esse diálogo pode ser institucional entre as outras estruturas formais de poder ou sociais.

O que se espera da atuação estatal é a adoção de um modelo coordenativo, multilateral e radial, ao invés do já superado conceito de administração estatal subordinativa, unilateral, hierarquizada e linear (MOREIRA NETO, 2007).

Este capítulo busca trazer elementos elucidativos acerca da quebra com aquela ideia de que a Corte Constitucional, no caso do Brasil, o STF, dispõe dos mecanismos necessários para ser a voz da razão, a limitação aos desmandos parlamentares e que diz o que a democracia é para aquela sociedade. "Nada garante que o controle de constitucionalidade será sempre certeiro, é verdade.” (MENDES, 2008, p. 189).

Duas serão as vertentes a exigirem ainda a competente elaboração teórica: aquela procedimental, de viabilização do diálogo social (quem ingressa, como ingressa, para que fins, com que prerrogativas); e também a forma pela qual essas eventuais contribuições serão incorporadas ao processo intelectual de construção da decisão. (VALLE, 2012, p. 50)

Assim, faz-se importante observar, sob a ótica da legitimidade para a propositura da ADI, exemplo máximo do controle abstrato de constitucionalidade que a partir do momento em que foi superado o antigo modelo que trazia como único legitimado o Procurador Geral da República, possibilitou-se uma pluralização do debate constitucional. Hodiernamente, as confederações sindicais, órgão dentre os legitimados constitucionalmente que mais se aproxima da sociedade, até mesmo pelas suas constantes aparições em debates políticos, são quem mais propuseram ADIs, 
conforme se depreende de consulta ao sítio virtual do Supremo. Interessante frisar que tais entidades não são legitimadas desde a promulgação da Carta Magna de 1988. (BRASIL, STF, 2012).

A situação mencionada serve para demonstrar que quanto mais se amplia o debate constitucional, maior é a tendência de participação social e de aproximação dos diálogos proferidos pela sociedade e pelo Direito.

Mas, indo além do mero rol de legitimados pela Constituição, a abertura que se defende nas linhas desse estudo é aquela não apenas para dar início ao processo constitucional, mas sim uma capaz de viabilizar a participação antes da tomada da decisão, ou seja, independentemente de quem tenha dado azo ao desenvolvimento da atividade jurisdicional constitucional, o que se defende é a possibilidade de participação popular na tomada de decisão por meio da realização de audiências públicas e da habilitação de amicus curiae, como formas de garantir a sua legitimidade democrática.

Ainda, o relatório de atividades do STF, a respeito do tema audiências públicas, traz os seguintes dizeres:

Desde a realização da primeira, em 2007, a audiência pública tem sido importante instrumento que, além de subsidiar os Ministros no julgamento de determinadas ações, também possibilita a participação da sociedade civil - pelos seus setores organizados - no enfrentamento da controvérsia constitucional. (BRASIL, STF, 2012, p. 53)

Então, a partir do momento em que o constituinte erigiu o acesso ao controle jurisdicional como garantia constitucional, o processo deve dar a exata resposta esperada pelas partes, sendo o minimamente interventivo. Em sendo assim, deve-se buscar ouvir os anseios da sociedade, razão pela qual passou-se a implementar a subjetivação do controle concentrado de constitucionalidade. A partir de então, o processo constitucional em abstrato passou por um giro interpretativo procedimental.

Dessa forma, independentemente, de quem tenha dado início ao processo constitucional objetivo, o presente trabalho busca demons- 
trar que a realização de audiências públicas nos processos de controle de constitucionalidade reforçam o argumento que a garantia do acesso à Jurisdição traz para o Poder Judiciário muito mais do que uma guarida contra as possíveis investidas despóticas dos demais Poderes, incorpora o conceito de democracia e legitimidade de suas decisões.

O Judiciário, sobremaneira o STF, não pode ser recluso em si mesmo, confiante na infalibilidade de suas decisões, nem achar que a mera aplicação do estrito Direito, sem levar em consideração todo um conjunto de fatores sociais é suficiente para que se traga uma decisão que possa ser aceita e adimplida pela sociedade, assim, o diálogo por meio da abertura do processo de formação da decisão se mostra como uma solução para minimizar a distância entre uma corte superior e os jurisdicionados que irão cumprir a decisão.

Conrado Hübner Mendes, em interessante ensaio, aborda os avanços que a instalação de uma Corte Deliberativa traria à jurisdição constitucional desenvolvida no Brasil, uma vez que nesse espaço ocorreriam os embates entre as razões expostas, havendo em cada fase uma mudança entre os personagens envolvidos na deliberação (MENDES, 2012).

Contudo, o citado doutrinador é bastante crítico ao afirmar que o STF adota uma postura solista, mesmo após a implementação das audiências públicas (MENDES, 2012, p. 73) 1 .

É importante que se diga, também, que a emenda ao regimento interno do STF que viabilizou o início da realização das audiências públicas é bastante lacunosa, a partir do momento, em que não se preocupou em estabelecer o procedimento para realização das audiências, tendo sido adotada, por exemplo, na primeira audiência um modelo de processo adversarial, tendo os interessados realizado suas sustentações de forma favorável ou contrária a validade da lei de biossegurança.

\footnotetext{
${ }^{1}$ A seguinte passagem demonstra a opinião do autor acerca da ausência da característica deliberativa no STF: Sob a perspectiva deliberativa, continua a ser um ente periférico e inexpressivo. Transformar um "tribunal de solistas" num tribunal deliberativo requer mais que rearranjos procedimentais. Exige que juízes, pessoalmente, entendam e valorizem o espírito da deliberação. Que se tornem, enfim, deliberadores.
} 
Entretanto, tal situação acaba por inviabilizar, por exemplo, as posições intermediárias como, por exemplo, daqueles que vislumbravam a possibilidade de utilização de embriões que não possuíam mais viabilidade de serem utilizados (LIMA, 2012).

Nesse sentido, cumpre mencionar que na primeira audiência pública (ADI n. 3.510) realizada houve a habilitação de amici curiae, mas também ocorreu que algumas entidades apenas quiseram se manifestar no sentido de apresentar pesquisas científicas ou de opinião (VALLE, 2012).

$\mathrm{Na}$ audiência pública referente à importação de pneus usados (ADI n. 3.150), o seu procedimento se caracterizou pela diferença em relação à primeira audiência pública, uma vez que, ao invés de determinar as exposições em blocos favoráveis e contrários à norma objeto de controle, nesse segundo momento buscou-se realizar a atividade de uma maneira alternada, intercalando sujeitos contrários e favoráveis à norma controlada (VALLE, 2012).

$\mathrm{Na}$ audiência pública atinente ao aborto de fetos anencéfalos outra característica chama a atenção, daquela vez o relator da ação, além de se manifestar sobre os habilitados realizou convites a outras pessoas e entidades. Além disso, a ordem das apresentações não foi determinada pelo conteúdo da opinião, mas sim pelo segmento ao qual o orador integrava, sendo no primeiro dia as entidades religiosas, no segundo, especialistas técnico-científicos; no terceiro, os demais segmentos sociais. Inclusive foi permitida a formulação de perguntas pelos Ministros integrantes da mesa, técnica que agora se tornou comum às audiências (VALLE, 2012).

Outro aspecto que passou a reger as audiências públicas é a busca pela adoção de um modelo menos adversarial e mais cooperativo, por meio do prévio estabelecimento de um cronograma que determina a ordem das apresentações, essa técnica foi utilizada na última audiência pública realizada pelo STF, que aborda a constitucionalidade do programa Mais Médicos (ADI n. 5.037 e ADI n. 5.035), as biografias não autorizadas (ADI n. 4.815), Financiamento de campanhas eleitorais (ADI n. 4.650) e Regime Prisional (RE n. 641.320) (BRASIL, STF, 2013). 
Interessante ainda destacar que, talvez pela falta de pedido de habilitação de interessados suficientes, o prazo para requerer a habilitação e participar das audiências públicas acerca do novo marco regulatório da TV por assinatura no Brasil foi prorrogado, mesmo tendo sido concedido, inicialmente, um lapso temporal hábil, sob a justificativa de buscar ampliar ao máximo o número de participantes (BRASIL, STF, 2014).

Não está equivocado o raciocínio que afirma que a presença do diálogo social no STF, mesmo que ainda não se tenha chegado a um procedimento ideal para a sua realização, muito disso devido à adoção de um modelo de processo inquisitorial, é inevitável que ocorra e que se amplie o rol de situações cabíveis, a abertura para a sociedade, até mesmo para conferir um maior grau de legitimidade às decisões judiciais.

\section{As Audiências Públicas como um Novo Meio de Criação do Direito}

A partir do momento em que se passou a valorizar o conteúdo das normas constitucionais e, partindo da premissa de que uma carta política vale-se de inúmeras cláusulas gerais a fim de possibilitar o alcance das mais diversas situações sociais, surge o problema em se definir quem seriam os intérpretes e como se alcançar o conteúdo dessa interpretação diante da jurisdição constitucional concentrada, até mesmo porque ela irá produzir efeitos erga omnes.

Bastaria a atuação dos ministros do STF na atividade interpretativa da Constituição? Apenas a atuação dos legitimados previstos na Constituição para deflagrar o processo constitucional objetivo seria suficiente para se atribuir uma natureza democrática à jurisdição constitucional?

Transferir a um dos órgãos do Governo a prerrogativa e as garantias para decidir em última instância acerca dos atos oriundos da atividade legislativa, ocasiona, em verdade, atribuir a esse mesmo poder, no caso brasileiro, o Judiciário, a responsabilidade sobre os destinos de um país (APPIO, 2007). 
Os tribunais, indiscutivelmente, contribuem sobremaneira para a descoberta da vontade e atualização das normas constitucionais. Contudo, esse não pode ser o único espaço de deliberação, até mesmo porque não se pode pensar o Direito Constitucional como um conjunto de agentes políticos, que por intermédio de advogados, promovem demandas junto ao Poder Judiciário (MENDES, 2008).

Conforme fora dito em capítulo anterior, nesta investigação, a teoria intitulada de jurisprudencialização do Direito Constitucional teve espaço por causa da importância trazida aos precedentes judiciais. Se o precedente possui força vinculante, nada mais democrático do que permitir a participação daqueles que serão alcançados por tais decisões.

Acerca do tema, as palavras de José Luis Bolzan de Morais (2011, p. 163):

Se a estrutura normativa do atual Estado Democrático de Direito e as dificuldades de implementação dos seus conteúdos característicos conduzem a uma maior presença do Poder Judiciário, com a finalidade de oportunizar a concretização dos direitos fundamentais, sobretudos os sociais, isso leva à afirmação de que ele não pode exercer, nos tempos atuais, apenas uma função jurídica técnica e secundária, ante a ausência da produção primária incumbida ao legislador e ao gestor, mas se apresenta como um ambiente no qual se travam os grandes embates definidores do projeto de sociedade que se pretende construir [...].

As audiências públicas, então, assim como é o caso da intervenção do amicus curiae, surgem como a abertura de um diálogo da Corte Constitucional, que, destaque-se, não possui o dever de realizá-las, no sentido de realizar o dogma constitucional da democracia.

O princípio democrático surge como a busca pelo objetivo de estabelecer, de forma rígida, os mecanismos do seu exercício, por meio de premissas, dentre outras, como as da representatividade, o procedimento legislativo e os instrumentos da democracia. Por causa disso foi que a jurisdição constitucional surgiu e foi encarada durante muitos anos, apenas como um limitador ao poder do legislador positivo, ou seja, como uma 
força garantidora da validade das normas sempre tomando como paradigma o texto constitucional.

A possibilidade da abertura judicial à dimensão participativa do princípio democrático é objeto de discussão no campo do processo civil, a partir da adoção de um chamado processo cooperativo, no qual se exige das partes uma atuação mais proativa no processo de formação da decisão judicial.

Não destoa desse raciocínio a ideia de que esse modelo de processo também possa ser adotado pela jurisdição constitucional, especificamente no controle concentrado por causa dos seus efeitos se produzirem de forma abstrata (VALLE, 2012).

Contudo, não se poderia deixar de abordar o viés interpretativo trazido por meio do neoconstitucionalismo, quando os enunciados das constituições deixaram de ser textos limpos, diretos, claros e enxutos, como ocorria no modelo de Estado Liberal, excessivamente individualista, para assumirem contornos programáticos, promessas estatais e tiveram que tutelar direitos sociais vários, que sempre tendem a se expandir, necessitando, dessa forma, valer-se de cláusulas gerais, com a inauguração do modelo de Estado Social.

Essa é a grande virada hermenêutica trazida para a jurisdição constitucional. Enquanto no Estado Liberal bastavam leis que regulassem e controlassem os poderes estatais, no Estado Social surge a necessidade da implementação dos direitos fundamentais.

Nesse momento o espaçamento entre os poderes estatais passou a diminuir, pois as promessas constitucionais precisam ser implementadas por meio da legislação infraconstitucional, atuação típica do Legislativo, ao mesmo passo em que a Constituição deve ser defendida pela Corte Constitucional, no Brasil, função típica do Judiciário, nesta senda, a não implementação de um direito fundamental, além de violar as garantias trazidas à sociedade, culmina pelo desrespeito à Constituição.

Em virtude dessas situações é que as Cortes Constitucionais passaram por momentos de mudança de paradigmas, de suas próprias decisões, vide o que ocorreu no Brasil em relação à forma como o mandado de 
injunção passou a ser tratado pelo Judiciário. Tudo isso com vistas à persecução do Estado do bem estar social, welfare state.

$\mathrm{Na}$ verdade, aquele conceito de Estado mínimo, limitado às leis acaba sendo superado pelo modelo de Estado prestador de atividades administrativas, que não se limitam apenas aos serviços públicos, enfatize-se, e isso acaba por alterar o próprio entendimento de democracia.

Surge então um novo Estado democrático de direito, no qual as políticas públicas ocupam o centro das promessas estatais constitucionais, sobre o tema, merecem destaque as palavras abaixo transcritas:

Em um novo ambiente, de um lado de aprofundamento da inclusão democrática - formal e material - e de outro da crise estrutural - acompanhando a crise conceitual - que vai afetar a fórmula de compromisso do Estado Social, é a função jurisdicional - como sistema de justiça - que, como guardião e realizador da Constituição, passa a ter seu espectro de atuação reforçado, assumindo-se como ambiente político para o debate e a tentativa de consolidação do projeto constitucional, no que ficou reconhecido como judicialização da política e politização do jurídico, conduzindo ao que nomeamos de jurisprudencialização das Constituições, já em 2002 [...]. (MORAIS, 2011, p. 170)

O que aconteceu é que as relações sociais passaram, cada vez mais, a ser geridas pelo Judiciário e com o crescimento da jurisdição constitucional, cada vez mais, a sociedade passou a ter interesse em participar do processo de tomada de decisão acerca das matérias constitucionais. Este cenário então traz desafios e coloca em xeque a legitimidade da democracia representativa clássica. Não mais basta à democracia o atendimento ao princípio da maioria.

Com base nessa premissa de redefinição das estruturas institucionais, houve a necessidade de uma nova análise do papel do Judiciário, saindo da postura de contralegislador e de defesa das minorias, contramajoritário, para um verdadeiro ambiente de discussão e realização das promessas políticas constitucionais. 
Para defender essas minorias o Judiciário, ao realizar as audiências públicas, busca, na verdade, fazer um mapeamento do dissenso em toda a sua extensão e complexidade para definir quais pessoas serão alcançadas pelos efeitos da decisão proferida acerca da norma controlada, quais as possíveis repercussões sociais da decisão proferida, tais elementos são indispensáveis para que se alcance uma decisão adequada (VALLE, 2012).

Nesse sentido, conforme trazido nesta investigação, no capítulo atinente às mudanças do Estado, a partir do momento em que as constituições passaram a trazer expressões dotadas de um alto grau de abstração, parece ser imprescindível que o juiz constitucional valha-se de novos mecanismos de informação para promover o desvelamento da norma constitucional.

Essa é a grande proposta deste trabalho acadêmico, a abertura do processo constitucional a fim de garantir a participação social como uma forma de resgatar a legitimidade das decisões proferidas em sede de controle objetivo de constitucionalidade em consonância com a nova feição que o Estado deve assumir para alcançar o bem estar social, partindo de um ideal habermasiano sobre a democracia deliberativa.

Tais premissas não estão dissociadas do próprio conceito de poder constituinte que "[...] é o poder que cabe ao povo de dar-se uma constituição.” (SILVA, 2007, p. 67).

Por causa disso é que a jurisdição constitucional deve ser vista como "[...] o embate entre argumentos e contra-argumentos que racionaliza o processo decisório democrático.” (SOUZA NETO, 2006, p. 129).

Resta claro que o que busca com as audiências públicas é a realização de uma deliberação, ou seja, um espaço para que os diversos participantes possam expor suas opiniões num modelo de troca de argumentos. Contudo, não se pode olvidar que um estado democrático de Direito se mostra imperioso para que haja a instauração de tal embate ideológico, pois em liberdade e igualdade não haverá diálogo verdadeiro e legitimador, mas sim apenas uma contrafação de um processo democrático de tomada de decisão. 
Destaque-se que a deliberação reside no processo de tomada da decisão. Assim, nada mais legítimo e democrático do que permitir a participação da sociedade como protagonista no processo de formação do convencimento e da decisão jurisdicional que irá repercutir, diretamente, sobre todos.

Esse é o principal pilar para que se viabilize a realização de audiências públicas e que se permita a habilitação do amicus curiae na relação processual. Nada mais faz o Judiciário do que conferir legitimidade democrática às suas decisões a partir do momento em que realiza uma abertura cognitiva do sistema jurídico para abarcar expectativas e frustrações quanto à sua futura decisão.

Habermas não traz um conceito de legitimidade pautado apenas pela legalidade, mas sim no fato de o procedimento corresponder com a prática discursiva, ou seja, não basta o procedimento, mas, tão importante quanto ele é a sua justificação.

Percebe-se, pois, que as ideias trazidas por Habermas pregam a valorização do respeito ao campo correto para a construção do procedimento, o Legislativo, e a legitimidade advinda deste, desde que justificada, consentida.

Então, trazendo para a jurisdição constitucional concentrada, o procedimento para a sua realização foi construído no Legislativo e lá mesmo já houve a previsão para a sua abertura cognitiva com a realização de audiências públicas e a permissão da participação do amicus curiae, isso com vistas a justificar, socialmente, uma decisão trazida por onze pessoas, ministros do STF, que deverá ser cumprida por toda a sociedade.

Assim, de nada adiantaria a permissão da participação popular no processo de tomada da decisão, se não houvesse a sua efetiva capacidade de influenciar os julgadores, da mesma forma, a decisão jurisdicional que observa os anseios da sociedade pode até não ser bem recebida por ela, mas, uma vez que tenha sido justificada, será compreendida e, naturalmente, adimplida.

Nessa mesma esteira de raciocínio, cabe fazer alusão ao fato de que o procedimento per si não é mais suficiente para conferir legitimidade a 
um poder ou decisão, em sendo assim, o STF, ao mesmo tempo em que adota um procedimento democrático de formação de decisão, também cria para si mesmo um dever de resposta à sociedade, numa espécie de modelo de processo cooperativo.

Por isso mesmo é que o Estado precisa ser o garantidor dos direitos fundamentais, para que, dessa forma, se consiga promover um processo deliberativo inclusivo.

Assim, tanto as audiências públicas quanto a participação do amicus curiae coadunam com esse raciocínio.

Contudo, a realização das audiências públicas não possui um procedimento específico, bem como, apesar da importância, o comparecimento dos ministros ainda é baixo, talvez até mesmo por causa da discricionariedade da própria realização da consulta social, tornando tal prática, ainda, ineficaz.

\section{A Impossibilidade da Aplicação do Teorema de Condorcet às Audiências Públicas}

O processo de formação de uma decisão judicial envolve a superação dos elementos de incerteza e isso faz nascer a necessidade de se agregar outros atores, preferencialmente pessoas que possam contribuir de forma técnica e acrescentar valores que possam contribuir para a superação das dúvidas.

Assim, o Teorema de Condorcet, formulado pelo matemático francês de mesmo nome, no século XVIII, traz importantes colaborações para o tema objeto da presente investigação.

A teoria tem como ponto central a ideia de que a probabilidade de uma resposta correta ser adotada por um grupo majoritário aumenta, tendendo a $100 \%$ à medida que o grupo cresce, uma vez que os grupos escolherão melhor do que os indivíduos, e grandes grupos, melhor do que os pequenos, desde que presentes duas condições, a saber: 1) as decisões sejam tomadas seguindo um modelo majoritário, e; 2) cada pessoa tenha maior chance de estar correta do que errada (VALLE, 2012). 
Desdobrando a teoria, é fácil perceber que, diante de argumentos racionais e objetivos, o matemático francês afirma que as decisões da maioria tendem a ser mais corretas ao mesmo tempo em que essa maioria detenha conhecimentos técnico-científicos aptos a viabilizar uma opinião com um alto grau de probabilidade de estar correta.

Destaque-se que Carlos Santiago Nino defende implicitamente a aplicação do Teorema de Condorcet no seu modelo deliberativo de democracia, uma vez que parte da premissa de que, quanto maior for o número de pessoas satisfeitas com a decisão, a solução tenderá a ser correta, já que o resultado correto seria aquele que potencializasse a satisfação dos interesses protegidos por esses direitos (NINO, 2003).

Essa teoria não parece ser a mais correta, quando do manejo das audiências públicas, até mesmo porque no campo jurídico a decisão envolverá, necessariamente, a ponderação de valores, por isso mesmo, são não objetivos.

Não é critério suficiente para conferir legitimidade às decisões judiciais uma maioria, principalmente, porque a atividade jurisdicional deve ser pautada pela defesa das minorias, isto é, precisa adotar uma postura contramajoritária, a fim de permitir que essa minoria tenha voz e seja ouvida dentro de um processo delineado pelo contraditório.

É bem verdade que esta investigação busca aproximar a legitimidade da jurisdição constitucional à teoria procedimental de interpretação constitucional, portanto, é imperioso dizer que a racionalidade que Habermas vê necessidade de ser empregada na decisão se estabelece tendo como pressuposto a utilização de um argumento que obtenha maior densidade de aceitação (AGRA, 2005). Destaque-se que essa densidade deve ser entendida não como quantidade de pessoas que aceitaram o argumento, mas sim como aceitação racional do fundamento utilizado.

Nesse último caso, outro aspecto relevante diz respeito ao resgate da moral promovido pelo Direito, dando, assim, ênfase a um constitucionalismo e não apenas ao normativismo, razão pela qual as decisões judiciais, principalmente no âmbito do controle concentrado de constitucionalidade exercido no STF serão dotadas de um grande conteúdo moral. 
Outra análise sobre o teorema ora estudado diz respeito ao fato de que o matemático francês não se preocupou em observar como os grupos agiriam se soubessem que seriam afetados pela decisão que iriam formar.

O controle concentrado de constitucionalidade tem o condão de produzir efeitos erga omnes, isso significa dizer que até mesmo os participantes do processo de formação da decisão judicial serão alcançados pelos seus efeitos. Em sendo assim, de alguma forma a razão dos grupos poderia ceder espaço ao interesse plural.

Por outro lado, também, não se pode desconsiderar a opinião de uma maioria, até mesmo porque é um importante fator de legitimidade para uma decisão judicial.

$\mathrm{Na}$ verdade, o problema resta instaurado e aparentemente sem solução, cabendo, pois a realização de uma análise aprofundada sobre as opiniões ofertadas pelos participantes da audiência pública a fim de se estabelecer quais seriam os melhores argumentos para a resolução daquela situação específica.

O que o estado da arte no tema no direito norte-americano parece estar a sugerir é que diferentes matérias devam encontrar distintos graus de ampliação e seleção do universo de many minds que possa efetivamente contribuir para o aprimoramento da decisão. (VALLE, 2012, p. 106)

Assim, a importância do tema não reside em se analisar apenas a quantidade de participantes, mas sim em buscar uma real inteligência entre as informações apresentadas, o que aproxima a atividade de construção da decisão judicial em uma relação mais complexa do que a subsuntiva.

Insista-se, a quantidade de expositores ou de material produzido pelos defensores de um determinado ponto não são suficientes para agregar a necessária legitimidade à decisão, ainda mais, quando o Judiciário precisa agir como um órgão contramajoritário, a exemplo do que ocorreu no julgamento da ADPF n. 132, no qual o ministro Celso de Mello teve o cuidado de demonstrar que a atuação do STF foi em defesa de uma mi- 
noria que estava excluída de qualquer proteção jurídica com relação ao casamento e seus efeitos.

\section{Conclusão}

O STF, a partir do momento em que a sociedade brasileira passou a vivenciar uma Constituição cidadã, tornou-se um órgão cada vez mais presente no cotidiano, principalmente, diante de decisões polêmicas, como o reconhecimento jurídico das uniões homoafetivas, a utilização de células-tronco em pesquisas científicas, a interrupção da gravidez de fetos anencefálicos e a permissão para a realização da marcha pela maconha, apenas, para citar alguns exemplos mais recentes, decidindo sobre questões que influenciam toda a sociedade.

Dessa forma, questiona-se como alcançar os primados da democracia deliberativa e da legitimidade das decisões proferidas pelo STF, em sede de controle abstrato de constitucionalidade, que possui efeitos erga omnes, sem se permitir a participação e a oitiva dos que serão atingidos por tal decisum?

No mesmo sentido, surge a indagação: A participação dos que serão atingidos pela decisão confere legitimidade às decisões do STF em controle abstrato de constitucionalidade das normas?

A presente pesquisa teve como um dos principais marcos teóricos o estudo da evolução constitucional do processo brasileiro, a fim de sair de um modelo pautado pelo interesse individual, baseado no binômio interesse-utilidade, para uma premissa coletiva, na qual o processo serve para veicular a opinião do Judiciário acerca de algum tema que repercute na sociedade e precisa de uniformidade

Para que o Judiciário, em especial o STF, não se torne um Poder dissonante dos anseios sociais, até mesmo em virtude da necessária observância da garantia do acesso à Jurisdição, tem-se que uma abertura procedimental da jurisdição constitucional é um caminho a ser percorrido no sentido de se aprimorar os conceitos de democracia deliberativa e de legitimidade participativa, que são tão aguardados nas decisões oriundas 
da Corte Constitucional. E mais, se o STF levar em consideração as contribuições do amicus curiae e os debates nas audiências públicas, então haverá democracia participativa na Jurisdição constitucional.

O STF, por concentrar as funções de corte constitucional e corte suprema, precisa viabilizar o diálogo social para promover a construção de uma decisão jurisdicional calcada no recurso das many minds, ou seja, por meio da participação de atores legitimados para além do rol hermético e fechado trazido pela Constituição como sendo os supostos únicos intérpretes de suas normas.

Por outro lado, se o Supremo utiliza as audiências públicas como mera estratégia de legitimação formal, então, a democratização da jurisdição constitucional e a sua acessibilidade não estão ocorrendo. Essa é a principal preocupação que rege o tema, como descobrir se as opiniões ofertadas, nas audiências públicas, ou trazidas pelos amici curiae efetivamente são levadas em consideração.

$\mathrm{O}$ que se conseguiu extrair das decisões proferidas nas audiências públicas realizadas é que os Ministros efetivamente se manifestaram sobre os argumentos veiculados no diálogo social, o que leva a crer que, de alguma maneira, tais informações foram efetivamente analisadas, para serem consideradas ou descartadas no momento da construção da decisão.

Os institutos das audiências públicas e do amicus curiae possuem uma forte ligação, é o que se extrai da leitura da decisão do Ministro Ayres Brito na ADI n. 3.510, que tratou da utilização de células-tronco embrionárias e foi o leading case das audiências públicas. Ademais, a partir do momento em que se reconheceu amplos poderes ao amicus curiae, para além da mera apresentação de memoriais, a sustentação oral realizada por um especialista técnico em muito se aproxima do modelo adotado pelo STF quando da realização de uma audiência pública.

Em ambas as situações o que se busca é a abertura e a ampliação do debate mediante a participação de outros que não apenas os integrantes formais da relação processual, até mesmo para trazer elementos agregativos, devido à sua representatividade ou conhecimento técnico-científico, relevantes à solução da demanda. 
É fácil constatar que a habilitação de amici curiae nos processos de controle concentrado de constitucionalidade tem ocorrido com mais frequência do que as audiências públicas, apesar de o número de audiências públicas realizadas ser crescente no âmbito do STF, talvez até mesmo por causa da operacionalização dos trabalhos que são mais complexos em uma audiência do que na permissão da atuação do amicus curiae.

Não se pode deixar de falar que a abertura dialógica do processo constitucional concentrado não é sinônimo de ativismo judicial ou do emprego de exacerbado substancialismo, no sentido de formar uma decisão pautada apenas em valores pessoais dos julgadores. O que o Judiciário deve assegurar são os procedimentos para a participação social no processo de formação da decisão judicial, não tendo que aplicar valores substanciais para responder aos conflitos postos à sua análise.

A busca pela legitimidade fez com que o Direito se aproximasse da sociedade e de seus anseios, saindo de um mero discurso coercitivo e fazendo com que as suas decisões estejam socialmente respaldadas e adimplidas.

Deve-se levar em consideração que a abertura dialógica no âmbito do STF viabiliza a consecução de decisões substancialmente mais legítimas, razão pela qual não se pode resumir a análise acerca da realização das audiências públicas e da habilitação do amicus curiae como sendo uma discricionariedade do relator da ação. Pensar em sentido contrário é o mesmo que afirmar que o alcance de uma decisão legítima é também uma discricionariedade para o órgão julgador.

Outrossim, as informações obtidas na audiência pública ou trazidas pelo amicus curiae irão compor os autos e a sua desconsideração ou a observância resumida e descomprometida de tais argumentos demonstraria o interesse da Corte em não esclarecer o conteúdo da sua decisão, mas sim em estabelecer um reduzido diálogo social sob um pseudo discurso legitimador. 


\section{Referências}

AGRA, Walber de Moura. A reconstrução da legitimidade do Supremo Tribunal Federal: densificação da jurisdição constitucional brasileira. Rio de Janeiro: Forense, 2005.

APPIO, Eduardo. Controle de constitucionalidade no Brasil. Curitiba: Editora Juruá, 2007.

BRASIL. STF. ADI n. 2.130. [2012]. Disponível em: <http://redir.stf.jus. br/paginadorpub/ paginador.jsp?docTP $=\mathrm{AC} \& \operatorname{docID}=363431>$. Acesso em: 27 jul. 2012.

BRASIL. STF. ADI n. 4.679, ADI n. 4.756 e 4.747. [2014]. Disponível em: <http://www.stf.jus.br/arquivo/cms/audienciasPublicas/anexo/ AUDIENCIA_PUBLICA_TV_Despacho_de_Prorrogacao_Audiencia_ Publica.pdf $>$. Acesso em 22 jan. 2014.

BRASIL. STF. ADI n. 5.035 e ADI n. 5.037. [2013]. Disponível em: <http://www.stf.jus.br/arquivo/cms/audienciasPublicas/anexo/ ProgramacaoAudienciaProgramaMaisMedicos19_11.pdf $>$. Acesso em: 17 dez. 2013.

BRASIL. STF. ADI por legitimado. [2012]. Disponível em: <http://www.stf.jus.br/ portal/cms/verTexto. asp? servico $=$ estatistica\&pagina $=$ adiLegitimado $>$. Acesso em: 27 jul. 2012.

BRASIL. STF. Estatística de ADIs por legitimados. [2012].

Disponível em: <http://www.stf.jus.br/portal/cms/verTexto. asp? servico $=$ estatistica\&pagina $=$ adiLegitimado $>$. Acesso em: $27 \mathrm{jul}$. 2012.

BRASIL, STF. Relatório de atividades do ano de 2010. Disponível em: $<$ http://www.stf.jus.br/arquivo/cms/sobreStfConhecaStfRelatorio/anexo/ Relatorio2010.pdf. Acesso em: 27 jul. 2012.

CANOTILHO, José Joaquim Gomes. Estudo sobre direitos fundamentais. São Paulo: Editora Revista dos Tribunais, 2008. 
HABERMAS, Jürgen. Direito e democracia: entre facticidade e validade. Trad. Flávio Beno Siebneichler. Rio de Janeiro: Tempo Brasileiro, 1997. v. II.

MENDES, Conrado Hübner. Controle de Constitucionalidade e Democracia. Rio de Janeiro: Elsevier, 2008.

MENDES, Conrado Hübner. O projeto de uma Corte Deliberativa in Jurisdição Constitucional no Brasil. In: SOUZA, Rodrigo Pagani de. et al. Jurisdição Constitucional no Brasil. São Paulo: Malheiros Editores, 2012. p. 53-74.

MORAIS, José Luis Bolzan de. Audiências públicas: novas práticas no sistema de justiça brasileiro e o princípio democrático (participativo). In: STRECK, Lenio Luiz; ROCHA, Leonel Severo; ENGELMANN, Wilson. Constituição, sistemas sociais e hermenêutica. Porto Alegre: Livraria do Advogado, 2011. p. 161-188.

MOREIRA NETO, Diogo de Figueiredo. Mutações do Direito Administrativo. 3. ed. Rio de Janeiro: Renovar, 2007. p. 261.

NINO, Carlos Santiago. La constitución de la democracia deliberativa. Barcelona: Editorial Gedisa, 2003.

PINTO, Marcos Barbosa. Constituição e democracia. Rio de Janeiro: Renovar, 2009.

SILVA, José Afonso da. Poder Constituinte e Poder Popular (estudos sobre a constituição). São Paulo: Malheiros Editores, 2007.

SOUZA NETO, Cláudio Pereira de. Teoria Constitucional e democracia deliberativa: um estudo sobre o papel do Direito na garantia das condições para a cooperação na deliberação democrática. Rio de Janeiro: Renovar, 2006.

VALLE, Vanice Regina Lírio do. et al. Audiências públicas e ativismo: diálogo social no STF. Belo Horizonte: Fórum, 2012.

VESTENA, Carolina Alves. Participação ou formalismo? O impacto das audiências públicas no Supremo Tribunal Federal brasileiro. Rio de Janeiro: FGV, 2010. 
Jadson Correia de Oliveira é doutor em Direito pela Pontifícia Universidade Católica de São Paulo (PUC/SP) (2017). Mestre em Direito pela Universidade Católica de Pernambuco (UNICAP) (2014). Especialista em Direito Público pela Escola Superior da Magistratura de Pernambuco (ESMAPE) (2008). Bacharel em Direito pela Faculdade Integrada do Recife (FIR) (2006). Professor da Faculdade Sete de Setembro (FASETE), em Paulo Afonso, BA. Advogado.

E-mail: jadson@fasete.edu.br.

Endereço profissional: Rua Vereador José Moreira, n. 1.000, Faculdade Sete de Setembro (FASETE), Paulo Afonso, Bahia. CEP: 48.603-004.

Ivan Luiz da Silva é doutor (2009) e mestre (2002) em Direito pela Universidade Federal de Pernambuco e Graduação em Direito pela Universidade Católica de Pernambuco (1996). Procurador de Estado - Procuradoria do Estado em Alagoas e Professor da Faculdade Sete de Setembro (FASETE), em Paulo Afonso, BA. E-mail: ivanluiz.al@bol.com.br.

Endereço profissional: Rua Vereador José Moreira, n. 1.000, Faculdade Sete de Setembro (FASETE), Paulo Afonso, Bahia. CEP: 48.603-004.

Fernando Sérgio Tenório de Amorim é pós-doutor em Direito pela Université de Montreal, Centre de Recherches en Droit Public (Laboratoire de Cyberjustice), nos quais é Pesquisador Colaborador, em 2015, e é pós-doutorando em Direito pela Pontifícia Universidade Católica do Rio de Janeiro PUC-Rio. Professor visitante na Université de Montréal, 2017. É doutor, 2011, e mestre, 2006, em Direito pela Universidade Federal de Pernambuco. Possui graduação em Direito pela Fundação Educacional Jayme de Altavilla (CESMAC) em 1991 e em Jornalismo pela Universidade Federal de Alagoas em 1991. Professor da Faculdade Sete de Setembro (FASETE), em Paulo Afonso, Bahia. Procurador do Município de Maceió, AL.

E-mail: fs.amorim@uol.com.br.

Endereço profissional: Rua Vereador José Moreira, n. 1.000, Faculdade Sete de Setembro (FASETE), Paulo Afonso, Bahia. CEP: 48.603-004. 